\title{
Menéndez Pelayo y la Literatura Comparada
}

\author{
Menéndez Pelayo and Comparative Literature
}

\author{
Miguel Ángel Garrido \\ CCHS / CSIC
}

\section{RESUMEN}

El nacimiento del comparatismo literario tiene lugar entre la publicación de los primeros volúmenes de la Historia de las Ideas Estéticas y la edición de Orígenes de la novela. Es absolutamente imposible que la obra de don Marcelino, espíritu inquieto y lector infatigable donde los haya, esté al margen de los acontecimientos culturales que se estaban produciendo al hilo de su propia labor. Aunque no utilice la denominación literatura comparada como título de ninguno de sus trabajos, este artículo muestra, mediante un recorrido analítico y una pequeña antología de textos de su obra, la relación de Menéndez Pelayo con la disciplina que marca la renovación de los estudios literarios del siglo XX.

Palabras Clave: Menéndez Pelayo, historiografía literaria, Literatura Comparada, Escuela Española de Filología, filología de los siglos XIX y XX.

\section{ABSTRACT}

The birth of literary comparatism takes place between the publication of the first volumes of the History of Aesthetic Ideas and the editing of Origins of the Novel. It is absolutely impossible for the work of Don Marcelino, of restless spirit and a tireless reader, to not be involved in the cultural events taking place in line with his own work. Although he does not use the term comparative literature as the title of any of his works, this article shows, through an analytical review and a brief anthology of his work, Menéndez Pelayo's relationship with the discipline that marks the renewal of twentieth-century literary studies.

Key words: Menendez Pelayo, Literary Historiography, Comparative Literature, Spanish School of Philology, Nineteenth-Century Philology, Twentieth-Century Philology.

Cabría preguntarse si tiene sentido plantear la cuestión de la Literatura Comparada al tratar de don Marcelino, habida cuenta de que no existe ni un solo capítulo, ni un solo apartado ni un solo intertítulo de su abultada producción en que se utilice esta denominación. Sin embargo, si abrimos un manual cualquiera de Literatura Comparada encontramos afirmaciones como la que sigue que nos pone evidentemente en un compromiso: «los últimos 
quince años del siglo XIX y los primeros años del XX asistieron al nacimiento, consolidación institucional y reconocimiento académico de la Literatura Comparada: en esos decenios, entre 1885 y 1905, se publicaron las primeras monografías clásicas del comparatismo, se crearon las primeras cátedras universitarias de literatura comparada, se fundaron las primeras revistas y aparecieron los primeros textos programáticos sobre su naturaleza, sus principios, métodos y fines» (Vega y Carbonell, 1998:13). O sea, el nacimiento del comparatismo tiene lugar entre la publicación de los primeros volúmenes de la Historia de las ideas Estéticas y la edición de Orígenes de la Novela, que nuestro autor acomete en 1905 a la vez que el plan de la publicación de sus Obras Completas. Es absolutamente imposible que la obra de don Marcelino, espíritu inquieto y lector infatigable donde los haya, esté al margen de los acontecimientos que se estaban produciendo al hilo de su propio trabajo, tanto más cuanto que no podemos pensar tampoco en alguna suerte de aislamiento. Es cierto que Menéndez Pelayo no se dedicó al turismo científico y solamente gastó lo que hoy parecerían ridículas cantidades al Ayuntamiento de su ciudad, a la Diputación o al Ministerio para viajar por diferentes bibliotecas mientras tenía la edad mínima exigida que le permitiera optar a cátedra, pero también lo es que mantuvo un contacto continuo, atestiguado en su copiosa correspondencia, con el mundo científico de su tiempo.

\section{EL PROGRAMA DE DON MARCELINO}

La Introducción y Programa de Literatura Española que Menéndez Pelayo preparó para su oposición a cátedra de la Universidad Central en $1878^{1}$ no contiene ninguna mención explícita a la Literatura Comparada por cuanto se trataba de diseñar el mapa de los estudios de literatura española, estableciendo en lo posible los límites diferenciadores de toda producción que no cupiera bajo ese nombre. Ciertamente, don Marcelino advierte desde la primera línea que no separa «historia» (que el estudio de la Literatura es historia se da por supuesto) de «crítica» ya que, sin ésta, no cabe, a su parecer, una verdadera historia, pues ¿cuáles serían los objetos susceptibles de historización si no se ha hecho sobre ello algún tipo de discernimiento, aunque sea implícito?

Sí distingue entre las posibles acepciones de literatura para aclarar que se va a referir al arte que se fabrica por medio de las palabras y no a la teoría literaria (existían cátedras de Retórica y Poética) ni a la acepción etimológica que permite entender el término en diversos idiomas («el alemán», dice don Marcelino, pero también el español) como bibliografía.

Abraza, pues, desde el paradigma historicista, común en la época, que debe

\footnotetext{
${ }^{1}$ El programa fue publicado íntegro por primera vez pon Miguel Artigas en la revista Cruz y Raya, 1934.
} 
estudiar las obras y los escritores españoles, lo que lejos de dejar la cuestión resuelta plantea un problema nada lejano al de la literatura comparada, como se verá.

De entrada, se opone don Marcelino a los que defienden el «exclusivismo castellano» para la noción de «literatura española». Ni las razones de nacionalidad ni las de lengua le parecen convincentes. Pocos, salvo los nacionalistas acérrimos, estarán hoy en desacuerdo con don Marcelino cuando descalifica la pretensión de condensar todas las fuerzas vivas de un pueblo «en una unidad panteística, llámese estado, genio nacional, índole de raza» (Pro:.5). También se puede aceptar que son lábiles las fronteras semánticas entre los términos «nación» y «estado», habida cuenta, por ejemplo, de que hoy la gran Nación norteamericana está compuesta de Estados, mientras que el Estado español agrupa naciones (o «nacionalidades»). Para que se tuviera en cuenta la nacionalidad como contenedor de una literatura propia, Menéndez Pelayo exige a esta entidad no solamente unidad de territorio y política, sino «religiosa, legislativa, linguiística, moral... et sic de caeteris»... Nada menos.

En cambio, resulta sorprendente la noción de «nacionalidad literaria» que propone. Muchos estaríamos dispuestos, y más en este período de la mundialización, a aceptar por razones lingüísticas y otras que la literatura inglesa y la norteamericana sean una (más cuesta arriba se hace integrar otras literaturas en inglés) y, desde luego, a integrar la literatura española (castellana) con la de «México y las de las repúblicas del Sur», pero se nos hace problemático descubrir la «imponente unidad de la literatura italiana desde remotas edades con no haber constituido Italia una nación desde que se deshizo el Imperio Romano hasta muy modernas revoluciones». Y esto último se nos hace cuesta arriba no por razones de geopolítica, sino lingüísticas.

Sin embargo, Menéndez Pelayo se resiste a identificar literatura castellana con literatura española y, planteado el proyecto como la historia de la literatura salida del solar de la Hispania romana, resulta efectivamente chocante que Alfonso X sea considerado español como historiador y no como poeta «porque las Cantigas están escritas en gallego» ¿Por qué fijarse en Castilla y no en Portugal y Cataluña?

Y no se reduce esta integración a la situación de la Edad Media. Dice con razón que «ni siquiera la historia literaria de los siglos XV y XVI, la podríamos comprender desde el punto de vista exclusivamente castellano. Haríamos un cuadro del renacimiento sin que en él apareciera la corte napolitana de Alfonso $\mathrm{V}$, una historia de la novela picaresca en que faltara el precedente del Livre de les dones, un catálogo de libros de caballería sin Tirant lo Blanch, no apreciaríamos en su justo valor las innovaciones métricas de Boscán y Gil Polo, al buscar los orígenes de la novela pastoril dejaríamos olvidado el autor de Menina e moça al paso que tendríamos que incluir a Jorge de Montemayor, tan portugués como aquel, solo porque escribió en nuestro romance. Aparecerían los géneros acéfalos, ni sabríamos de donde vienen ni a donde van las tendencias literarias». (Pro: 7). 
Pero, así las cosas, literatura española sería la escrita por españoles y por tales hay que tener todos los habitantes de la península ibérica. Se acoge don Marcelino a las afirmaciones de Almeida-Garret: «Mientras Castilla estuvo separada de Aragón y ya mucho después de unida, nosotros y las demás naciones de España, aragoneses, castellanos, portugueses, todos éramos, por extraños y propios, comúnmente llamados «españoles», así como hoy llamamos «alemán» al prusiano, sajón, hannoveriano, austriaco: así como el napolitano, el milanés, el veneciano y el piamontés reciben indistintamente el nombre de italianos. La pérdida de nuestra independencia política después de la jornada de Alcazarquivir, dio el título de reyes de las Españas a los de Castilla y Aragón, título que conservaron aún después de la gloriosa (sic) restauración de 1640».

Dice el programa que no se minusvalora el componente de la lengua en la determinación de la identidad de una literatura, pero que no se puede reducir tal identidad a la adscripción linguiística. Se aduce el hecho del latín renacentista en que escribían como «lingua franca» los académicos del renacimiento. ¿Habría, pues, que acoger como literatura española los textos latinos del siglo XVI?

Según Menéndez Pelayo hay una cuestión de «estilo» en eso de la nacionalidad literaria. No parece dudoso que se esté refiriendo al supuesto del Volksgeist, pero ese «espíritu del pueblo» se materializa en la lengua por la modalización que introducen en ella hechos e historia de una cultura y, a la vez, se configura en sus perfiles por la formalización que a toda cultura somete la lengua en que se expresa.

Apartado de un plumazo el vascuence («rama éuskara o turania»), pareciera que estamos llegando a una preconcepción de «nacionalidad literaria» compuesta por los textos de una nación-cultura, la Hispania romana, cuyas lenguas, por ser derivadas de una misma lengua, el latín, y por tener textos en esa lengua, el latín del humanismo, presentaría una determinada unidad en lo idiomático (hablamos de «dialectos» del latín) y una cierta unidad en lo «estilístico» (son innegables las relaciones con los antecedentes de la literatura latina, y entre sí, del conjunto textual en cuestión). Pero no. Se sigue con un salto hacia delante. «¿No sería acéfala nuestra historia, si en ella faltase la literatura hispano-romana, ya gentil, ya cristiana?», se pregunta don Marcelino (Pro: 9).Y he aquí por donde cargamos también con el latín.

La «nación literaria» es ahora cuestión de estilo. Don Marcelino defiende que son caracteres de la literatura española «la pompa y altisonancia de dicción, el abuso de la hipérbole, lo exuberante y encrespado, junto con cierta aspereza y genio indómito anunciado ya en aquellos cordobeses que celebraron a Metelo, pingue quiddam sonantes atque peregrinum; en Sestilio Hena, acusado por Marco Aurelio del mismo defecto, en Porcio Latron a quien llama Séneca fortem, agrestem quia Hispaniae consetuetudinis morem non poterat dediscere y, sobre todo, en Séneca y en Lucano». 
Excesiva parece esa identidad, aunque no sea el único que la formule. No alcanzan esos caracteres a todos. Incluso don Marcelino se da cuenta y echa mano de Quintiliano para disculpar como exceso generalizar sobre la negativa influencia de los hispano-latinos. La verdad es que tampoco parecen muy acordes los rasgos expuestos con los caracteres generales que atribuiría más tarde Menéndez Pidal a nuestra literatura. Pero otro argumento viene en su ayuda: el latín es desde el siglo IV la lengua eclesiástica oficial y, por ende, la lengua en que se expresa una «nacionalidad literaria» que en el cristianismo tiene uno de sus rasgos definitorios y permanentes. «El estudio de la literatura latino-eclesiástica tórnase además indispensable como antecedente para el de los orígenes de la lengua, del metro y de la rima y de casi todos los géneros literarios, incluso los cantares de gesta, incluso los libros de enxiemplos, que aparecen antes que en las vulgares en la lengua latina con la Disciplina Clericalis de Per Alfonso» (Pro: 11).

Si la «nacionalidad literaria» no tiene como base fundamental la lengua, es natural que surja una inquietud más, la de si incluir en la literatura española la obra de aquellos autores judíos y musulmanes que vivieron en el suelo de Hispania. Pocas dudas caben sobre la mutua influencia entre estas obras y otras redactadas en las lenguas romances, ninguna en el papel que tuvieron en la transmisión de ciertos géneros y en la mediación de la influencia griega. Por eso, no atribuir una influencia contundente a la lengua y entregarse a una vagarosa «nacionalidad literaria» podría dar lugar a una ampliación sin límites del proyecto. Don Marcelino cierra la puerta por las buenas y convierte lo que queda fuera en «influencias» («arábigas» y «semíticas»), lecciones aisladas del propio programa o en reconocimiento de antecedentes, porque « ¿de qué serviría negar, por ejemplo, que el libro de los Reys d'Orient y la Vida de Sta María Egipciaca son de origen transpirenaico cuando hierven en provenzalismos y cuando del segundo ha dado a conocer Mussafia los originales? Es muy conveniente, pues, para no cegarse ni empeñarse en descubrir el espíritu nacional donde no se halla, atender mucho a las literaturas extrañas, sobre todo a las que directamente han influido en la nuestra, como ésta a su vez en la de ultrapuertos (Pro: 13).

No es aquí la ocasión de volver a repetir una vez más lo inabarcable que es el mapa diseñado como programa por don Marcelino y la imposibilidad que tuvo en efecto de investigar completa cualquiera de sus rutas, pero sí es oportuno consignar cómo la ausencia del paradigma comparatista dibuja un cuadro de difícil coherencia. No se trata solamente de la literatura en lengua castellana, catalana y portuguesa y de su común origen latino, sino, se supone, de su prolongación en América, donde habría que abordar las literaturas en español de las nuevas repúblicas, así como la literatura en portugués de Brasil.

¿Qué decir aquí, pues, a propósito del «comparatismo» de don Marcelino? La falta de una perspectiva comparatista, siquiera implícita, en este programa da como resultado una suerte de cuadro cubista. Lo cierto es que cada 
elemento está bien visto, pero la composición del conjunto resulta forzada. Un programa de historia (comparada) de la literatura como la que se estaba empezando a aplicar por aquellos años, hubiera podido ofrecer un catálogo de literaturas afincadas en sus respectivas lenguas (castellana, catalana, portuguesa, etc. Y del árabe y del hebreo); una red de relaciones que describen sus mutuas influencias y dependencias (especialmente las dependencias del latín) y una taxonomía de perfiles discutibles y flexibles que, distribuyendo la producción entre entidades geográfico-políticas, pudiera dar cuenta del papel de las nuevas sociedades en el nacimiento de otras obras y géneros.

Un programa así bien podría considerar literatura española la producción en castellano de España y América hasta Rubén Darío y podría volver a considerar unitariamente la literatura que se escribe en Argentina o Chile, Colombia o Venezuela, Puerto Rico o Cuba, Perú o España, en esta hora de la mundialización. Los círculos concéntricos no tendrían límites y las fronteras geográficas o las divisiones administrativas no se impondrían como algo absoluto. Acabamos de citar en nuestra relación a Puerto Rico, Estado asociado de los Estados Unidos de América del Norte y podríamos añadir la literatura en español producida en los Estados Unidos por hispanos. Pero evitemos anacronismos. Quizás, con todo, podamos afirmar que si se hubiera considerado la metodología comparada, el programa habría evitado más de un problema (Cfr. Cabo Aseguinolaza, 2012).

\section{DON MARCELINO Y EL MÉTODO COMPARATISTA}

Aunque esto es así en el Programa, Menéndez Pelayo se refirió al comparatismo muchas veces a lo largo de sus obras, si tenemos en cuenta, además, que la necesaria práctica de la comparación es anterior a su denominación y, desde luego, a su instauración como disciplina. Ya en el volumen I de la Historia de las ideas Estéticas Menéndez Pelayo advierte que, al final de la Institutio oratoria de Quintiliano, se hace un ejercicio de «estética comparada», pues, tras enumerar los nombres de los grandes pintores griegos, constata que tal variedad se da también en el discurso de la palabra (p. 273). $\mathrm{O}$ sea, se hace referencia a una de las posibilidades de comparatismo que mencionarán algunos continuadores de la disciplina y se emplea la propia denominación que, convertida en cliché, servirá de seña de identidad.

En alguno de los manuales al uso se nos sigue recordando que se concede al gran crítico francés Abel-François Villemain el mérito de haber empezado a difundir ya el comparatismo en su curso universitario sobre literatura del siglo XVIII dictado en el año académico 1828-1829. Solamente después, en 1835, Philarète Chasles impartió en el Ateneo un curso ya explícitamente sobre literatura extranjera comparada y, en 1843, Adolphe-Louis Puibusque publicó una historia comparada de las literaturas francesa y española. Hacia 1868, Sainte-Beuve estableció la prevalencia del término comparada en vez 
de su pareja «-ativa», comparative, con la que solía alternar y que fue la opción preferida del inglés ( $\mathrm{R}$, Wellek, 1968).

A pesar de que se trata de la «prehistoria», no son desconocidos estos antecedentes para don Marcelino. Veamos. En el capítulo III del volumen I de Ideas Estéticas analiza la aportación de Villemain (1790-1870) a quien reconoce como renovador de la crítica francesa, pero piensa que le falta profundidad y le sobra retórica (p. 351). Las objeciones son muchísimas: Villemain no conoce la crítica alemana y desea quedar bien con todos. Conoce los clásicos griegos y latinos y los clásicos franceses, pero no la literatura medieval, ni las literaturas de España, Italia y Alemania. Tampoco poseía suficientes conocimientos de filosofía y ciencias. Están olvidadas sus comparaciones entre autores griegos y franceses (Píndaro-Bossuet), aunque fue un gran conocedor de Marco Tulio, fue «el último de los grandes ciceronianos». A Menéndez Pelayo, Villamin le parece poco «comprometido» en su Cuadro de la literatura del siglo XVIII cuya lectura no informa de cuál es el bando del autor ni en la diatriba entre clásicos y románticos ni en la posición a favor o en contra del ancien régime. Pormenorizando, Menéndez Pelayo echa en falta en su obra a los alemanes Wieland, Lessing, Herder, Kant, Schiller. Goethe. De Inglaterra faltan Swift, Fielding y Sterne; de Italia, Parini, Goldoni, Monti, aunque no falte Beccaria ni (con escándalo de Menéndez Pelayo) Filangieri. A España se la omite por completo. (p. 353). En fin, don Marcelino se ensaña con razón con un curso de Villemain sobre la Edad Media, digno del olvido y habla de su crítica de Píndaro para la que le faltaban conocimientos de Filología... ¡Comparada!

Menéndez Pelayo evoca una y otra vez la comparatística a los más diversos propósitos. Además de la citada, a propósito de Quintiliano, hay otra atinada mención de la acepción de la Literatura Comparada que compara entre las Bellas Artes y, así, invoca a Winckelman para reclamar una apertura a lo sublime que capacite a tal empresa. Tratando de Guillermo Schlegel recuerda que para comprender el Hipólito de Eurípides es preciso admirar los Dioscuros de Monte-Carvallo y el Meleagro y el Apolo del Vaticano (IE., III,: 140). Pero esto es lo más evidente, aunque, ni mucho menos, lo único. Están la «Fisiología comparada», conocida por Abentofail según se manifiesta en la especie de Robinsón islámico que escribió (ON: 48) y, más concretamente, la «Anatomía comparada» (ECF: 323); la «Psicología comparada», a propósito de la Antoniana Margarita (CE: 27) de Gómez Pereira, obra cuyo descubrimiento le llenó de gozo en su juventud cuando investigaba en los archivos sevillanos; la «Geografía comparada» cuya paternidad atribuye a Miguel Servet por su preparación de una edición del Tolomeo (H.H: 334); y, en fin, la «Legislación comparada», traída a colación en el discurso de ingreso de Eduardo de Hinojosa en la Real Academia de la Historia (ECF: 222), por no contar con la «Filosofía Comparada» que menciona en su respuesta a un discurso parlamentario de Castelar. 
La Mitología Comparada es también objeto de atención, pero no se refiere a la comparación entre relatos (salvo que ocasionalmente el contexto llene la denominación de este sentido), sino a la acepción más común de mitología. Veamos:

1. A Federico Schelling se le atribuyen conocimientos «positivos» de Mitología comparada (IE, II, IV:161).

2. Cree Menéndez Pelayo que Hegel ofrece elementos para la Mitología Comparada, como son su observación del ideal clásico de la condición antropomórfica y la reacción del politeísmo griego contra la simbólica oriental, aunque no llegue a desarrollarlos. Según don Marcelino, lo que Hegel pierde como investigador de Mitología Comparada, lo gana como crítico de arte (IE, II, IV: 213).

3. Subraya la importancia de la mitología comparada dentro del campo más amplio de los estudios del folclore, señalando la importancia de la revista Zeitschrift für Völkerpsychologie und Sprachwissenschaft en la relación entre mitología comparada, lingüística y desarrollo de las instituciones, básica en la noción de Volkgeist, y que tanto juego ha dado en la historiografía literaria romántica y posromántica. (IE, II, VIII, p. 297).

4. Rastrea en las interpretaciones comparatísticas en el mito de don Quijote, en Tristán e Iseo, Baarlam y Josafat o en la cultura de Hispania antes del cristianismo.

Son, desde luego, indagaciones comparatistas, pero no pertenecen a la metodología de la Literatura Comparada.

Sin embargo, yendo concretamente a nuestro asunto, podemos observar en la obra de Menéndez Pelayo un enorme interés por la Filología Comparada, denominación en que filología resulta un término de gran amplitud, que no solo acoge los estudios de lengua y de literatura, sino de todas las dimensiones de una lengua, su literatura y su cultura según el aliento propio con que siempre concibió su tarea.

En el tomo II de Las Ideas Estéticas («Introducción al siglo XIX, IV. Alemania e Inglaterra»), Guillermo Humboldt es señalado como uno de los padres de la Filología Comparada: "Y eso que, en los comienzos, no conocía las lenguas americanas ni el sánscrito y hasta 1814 o 1815 no abordó las malayas y polinesias ya estudiadas por nuestro Hervás y Panduro». Como acabo de señalar, «esta Filología Comparada es tan amplia y consigue un estatuto tan general que puede atribuirse un estatuto de ciencia social e, incluso, en su más amplio sentido, filosófica» (I.E, II.: 130).

Sin duda, es la enorme admiración que don Marcelino siente por el Catálogo de las lenguas de Hervás como «polígrafo» (Garrido Gallardo, 2012), lo que explica que sean tan numerosas las menciones de la Filología Compara- 
da que jalonan sus obras completas. En el tomo IV de Estudios y Discursos de Crítica literaria contiene una apología de este autor en toda regla: «el tiempo transcurrido desde la publicación de este trabajo, dice, solo ha servido para acrecentar su fama entre los sabios. A manos llenas explotaron este tesoro los más célebres filólogos modernos, alabanzas justísimas han tributado a su autor cuantos han tenido ocasión de leer esta obra. Carecía de precedentes la empresa de Hervás y Panduro; después ha tenido pocos imitadores A contribución puso sus trabajos Adelung para el Mitrídates, siguiendo su ejemplo su continuador, Vater».

Así, al subrayar el mérito de Hervás, reconoce la importancia de la Filología Comparada: "Cuantos eruditos han cultivado estos estudios, reconocen el mérito eminente de nuestro compatriota, que aparte de su acierto en la clasificación de las lenguas, tuvo la gloria de abrir un camino hasta entonces punto menos que inexplorado. Hoy que con tanto empeño se sigue el estudio de la Filología Comparada, que tantos progresos ha hecho en nuestro siglo, justo es que reivindiquemos para un compatriota nuestro el honor de haberla hecho adelantar más que escritor alguno de su tiempo».

Señala que Hervás registró para su trabajo «cuantas gramáticas y vocabularios de todos los idiomas y dialectos conocidos pudo haber a las manos, consultó verbalmente muchos misioneros que habían residido largo tiempo en países, sobre cuyas lenguas nada se había impreso y no perdonó estudio ni diligencia para procurarse cuantos datos le parecieron útiles».

Destaca que «procuró establecer la filiación y enlace de las lenguas, comprendió la importancia inmensa de los idiomas como expresión del espíritu de las razas y signo distintivo del carácter de los pueblos».

Y detalla así su aportación: «el tomo primero (decimoséptimo de su magna enciclopedia, la Idea) titúlase Catálogo de las lenguas conocidas y noticias de su afinidad y desemejanza. El segundo versa sobre el Origen, formación, mecanismo y armonía de los idiomas. El tercero se titula Aritmética de las naciones y división del tiempo entre los orientales, un Vocabulario polígloto, con prolegómenos sobre más de ciento cincuenta lenguas! El quinto contiene un Ensayo práctico de las lenguas, con prolegómenos y la Oración Dominical escrita en más de trescientas lenguas y dialectos. Bastan estas indicaciones para comprender el caudal inmenso de noticias filológicas recogidas en la obra de Hervás y Panduro. Contiene entre otras cosas una lista comparada de las sesenta y tres palabras más usadas en trescientas lenguas y dialectos. El número prodigioso de traducciones del Padre Nuestro fue acrecentado considerablemente por Adelung, que en el tomo primero de Mitrídates, incluyó la oración dominical en quinientas lenguas».

Hervás, insisto, es una referencia constante: en la evocación de Antonio Fernández Palazuelos, modesto poeta montañés, jesuita expulso, citado por el Padre Arteaga (EM: 10), o en la referencia general a la expulsión de los jesuitas, de la Historia de los heterodoxos españoles, en que Hervás es califi- 
cado también como uno de los primeros autores de «etnografía y antropología» (HE, III: 273) o a propósito del Diálogo de Juan de Mal Lara sobre la lengua castellana comparada con la griega (BHLC: 159) o de Benito Arias Montano (BT: 162). No cabe duda: Don Marcelino es un ferviente admirador de Hervás y Panduro y guarda un firme reconocimiento teórico hacia la Filología Comparada y hacia los españoles pioneros de la disciplina entre los que - todavía falta por decir - incluye como antecedente a Isidoro de Sevilla.

En cuanto a la disciplina de la Literatura Comparada propiamente dicha, el recorrido por la obra completa de don Marcelino lo acredita como un riguroso y atento observador contemporánea de su evolución.

En el discurso de respuesta en el ingreso de don Ramón Menéndez Pidal en la Real Academia Española, el 19 de octubre de 1902, manifiesta esa comprensión del fenómeno cuando alaba justamente el romancero de Durán y señala cómo son disculpables sus deficiencias en «una época en que todavía no se cultivaba la Literatura Comparada» (EDCL: 146). En el capítulo titulado La mil y una noche, un libro de cordel y una novela de Lope de Vega, a propósito de las «influencias arábigas» pondera la importancia del relato de la Doncella Teodor en el marco de la Literatura Comparada (EDCL: 220) con un talante del comparatismo más evolucionado y que no es solo de este momento ocasional. En la contestación al discurso de don Adolfo Bonilla y San Martín en la Real Academia de la Historia (16-3-1911) vuelve a invocar la Literatura de Cordel a propósito de los Libros de Caballerías.

En la Antología de Poetas Líricos Castellanos emerge también el comparatista. Se insiste en las limitaciones de Durán porque «todavía se sabía poco de la literatura Comparada» (APCL, I: 27). Se observa con acierto que la fuente de Los Milagros de Nuestra Señora de Gonzalo de Berceo no tenía que ser necesariamente la obra de Gautier de Coincy, pues un adecuado comparatismo demostraba que podían bastar las fuentes latinas (APCL, III: 180). Se aclara en el libro sobre Boscán que el progreso del comparatismo contribuye a aclarar la verdadera historia del endecasílabo español, que viene del Arcipreste de Hita.

A estas alturas, puede ya considerarse que tales estudios se han desarrollado y puede don Marcelino justificar por este hecho determinadas medidas que toma en la dirección de la Nueva Biblioteca de Autores Españoles.

\section{LA PRÁCTICA COMPARATista de MENÉNDEZ PElayo}

Es verdad que el sintagma literatura comparada implica en nuestro mundo académico, transcurrido más de un siglo, una polisemia extrema. Para calibrar la implicación comparatista de Menéndez Pelayo, podemos recordar el pronunciamiento de Van Thieghem (1924), que es el autor del manual clásico y más difundido de la materia, antes de que se empezase a vislumbrar el 
cambio de paradigma que se produce a mediados del siglo XX con la cristalización, en cierta medida como alternativa, de la disciplina Teoría de la literatura.

Van Thieghem, quien abraza el historicismo positivista como principio metodológico consciente, advierte de una nueva necesidad inexcusable a finales del siglo XIX y principios del siglo XX, la de tener en cuenta las influencias literarias recíprocas entre las literaturas nacionales cuya existencia había subrayado el Romanticismo. Nacía así la historia comparada de la literatura o, como se vino a llamar, la literatura comparada. Cuatro son las líneas de trabajo previstas por Van Thiegem (1924:8):

1. Historia de un tema o un motivo legendario o poético a través de literaturas diversas.

2. Caracteres y transformaciones de un género o de una forma literaria.

3. Fuentes extranjeras de una obra o parte de una obra.

4. Fortuna de un autor en un país extranjero.

Las tres últimas opciones son las preferidas de Van Thieghem que subraya cómo así se aportan conclusiones preciosas para una historia general de la literatura que él ya entrevé. Estudiaría en cada época los elementos comunes de las diferentes literaturas, y así se podría conocer con precisión, por ejemplo, qué ha sido el petrarquismo, el humanismo, el manierismo, el romanticismo o el realismo.

Por lo que aquí interesa, las líneas citadas parecen un índice para clasificar la obra de don Marcelino. ¿Qué mejor ejemplo, para el primer apartado, que las indagaciones sobre la obra del Arcipreste de Hita? En el segundo apartado se incluye, de la mano de Juan Boscán, el estudio de las transformaciones de una forma literaria italiana cuya importancia no han dejado de reconocer los estudios literarios posteriores hasta hoy. En tercer lugar, fuente extranjera de nada menos que La Celestina es el Pamphilus de Amore, relacionado, por cierto, con el motivo de De Vetula. Y, sobre todo, si Fernand Baldensperger, con su monografía Goethe en Francia (1904); Paul Van Thieghem con su tesis Ossian en Francia (1917) o Marcel Bataillon con Erasme et l'Espagne (1937) son figuras del comparatismo en su expresión más genuina, ¿qué decir de Horacio en España (1876) escrito por Menéndez Pelayo antes de que a nadie se le hubiera ocurrido otorgar para labores como ésta un nuevo nombre de disciplina? Además, antes de que las páginas de Van Thieghem que venimos citando dijeran que «no han de descuidarse los escritores de rango secundario, cuyo valor es incalculable para atestiguar un estado espiritual colectivo», esta práctica era ya habitual en las investigaciones de nuestro sabio, lo que, por cierto, criticaba Unamuno. Ofrecemos una pequeña antología de los ejemplos.

Primer ejemplo. Miremos el apartado de Juan Ruiz en la Antología de 


\section{Poetas Líricos Castellanos, parte primera («La poesía en La Edad Media»), capítulo V y detengámonos en el episodio de Doña Endrina (p. 284):}

Forma por si solo la quinta parte de la obra del Arcipreste, y es sin duda lo que trabajó con más esmero de estilo y menos desorden de composición. Solo una pequeña parte de sus bellezas proceden del original latino, y hasta cuando más directamente traduce, logra hacer suyo por los prestigios de su estilo desenfadado y brioso todo lo que toca. ¿Quién ha de decir, por ejemplo, que no son originales estos versos tan célebres y tan dignos de serlo, que hasta a los ojos de los retóricos clásicos han encontrado gracia, y que Martínez de la Rosa trae en su Poética como ejemplo de la animación y rapidez que el Arcipreste sabía imprimir a un ritmo tan lento?

Con arte se quebrantan los corazones duros,

Tómanse las ciudades, derríbanse los muros

Caen las torres altas, álzanse pesos duros.

Por arte los pescados se toman só las ondas,

Et los piés enjutos corren por mares fondas... (Copls. 592-593).

Y, sin embargo, no solo el pensamiento, sino las imágenes y hasta el giro de la frase son de Pánfilo:

Ars anims frangit et fortes obruit urbes,

Arte cadunt turres, arte levatur onus,

Et piscis liquidis deprehenditur arte sub undis,

Et pedibus siccis per mare currit homo.

A continuación, don Marcelino muestra cómo si en la marcha de los versos el Arcipreste no innovó en absoluto, resulta absolutamente original en adelante por la observación de los «efectos del amor» y por el modo gentil de insinuarlos. Y, nos ofrece, en fin, por ejemplo, una página de caracterización que solo el dominio de la literatura comparada puede brindar (pp. 288-289):

La influencia clásica se determina en el Arcipreste, no solo por la imitación del verdadero Ovidio y del falso, sino por las citas de moralistas, especialmente de los dísticos del pseudo Catón, por alusiones a las doctrinas astronómicas de Tolomeo y de los platónicos, y principalmente, por la intercalación de varios apólogos tomados evidentemente de las colecciones esópicas. En determinar los originales inmediatos, han trabajado muchos eruditos, especialmente Du Méril y Amador de los Ríos; pero a la verdad, sin positivo resultado, porque siendo tantas y tan semejantes entre si dichas colecciones, y siendo tan original el Arcipreste en el modo de contar sus fábulas, es casi imposible saber a punto fijo cuál de los Isopetes, Hórtulos y Fabularios que entonces corrían es el que usaba. Añádase una segunda dificultad, cual es el encontrarse simultáneamente algunos de estos apólogos en la tradición clásica y en la tradición oriental, como derivados de una remotísima fuente común, que no es otra que el apólogo indio. El arcipreste tomaba indiferentemente sus enxiemplos de libros latinos y de libros árabes, ora leyese estos últimos en su texto original, ora traducidos al castellano o al latín, como ya lo estaban todos los principales. Creemos, sin embargo, que proceden de la versión esópica veintiuno por lo menos de los apólogos del arcipreste, entre ellos, los dos 
tan célebres y tan dignos de serlo de las ranas que demandaban rey a D. Júpiter, y de el Mur de Monferrado y el Mur de Guadalajara, transformación españolísima de la fábula del ratón campesino y del ratón ciudadano. No creemos que el Arcipreste tomase directamente esta fábula de las epístolas de Horacio, autor poco leído en la Edad Media; pero la fábula existía antes de Horacio, y después de él entró en muchas colecciones. Por otro lado, es tal la originalidad del estilo del Arcipreste, y tales los detalles que añade, tomados de las costumbres de su tiempo, que en ocasiones hace perder hasta el rastro de los originales. ¿Quién reconocerá, por ejemplo, la sencilla fábula Lupus et Vulpes, judice Simia en la extensa parodia de costumbres curialescas que el Arcipreste tituló «del pleito quel lobo é la raposa hubieron ante don Gimio, alcalde de Buxía?».

\section{Y continúa sacando provecho del recurso a las «literaturas diversas»:}

La vocación de fabulista era en el Arcipreste tan innata como en Lafontaine. Ni uno ni otro se cuidaban de inventar los asuntos de sus apólogos: los tomaban donde los encontraban, los hacían suyos por derecho de conquista, desarrollaban a todo su sabor el contenido poético sin preocuparse mucho de la moralidad, y resultaban poetas originalísimos, tanto por la invención de los detalles pintorescos, cuanto por la intensa y graciosa ironía con que sacan consecuencia de su filosofía mundana. Nunca, antes de Samaniego, el arte del apólogo fue cultivado por ningún poeta castellano con tanta sal y agudeza como la que hay derramada en los enxiemplos del Arcipreste de Hita. Las mismas fábulas que Bartolomé Leonardo de Argensola suele intercalar en sus epístolas siguiendo el ejemplo de Horacio, resultan, aunque primorosamente versificadas, lentas fatigosas y descoloridas, si se comparan con el genial y no aprendido donaire del vetusto poeta alcarreño, que da claras muestras de haber estudiado cariñosamente los animales y de haber penetrado mucho en la intimidad de sus costumbres más en el campo que en los libros.

Y todavía queda por ponderar, entre otras muchas cosas, la comparatista (y, desde su estudio, innegable) percepción de otra influencia clásica más honda, «pero más velada» y de la cual el Arcipreste seguramente no tuvo conciencia, que es la influencia pagana, una «desenfrenada expansión de la alegría del vivir» que se manifiesta, por ejemplo, en la pompa triunfal con que Don Amor y don Carnal fueron recibidos en Toledo y termina en lo que llama don Marcelino kermesse brutal, algazara de voces discordantes e instrumentos, orgía estrepitosa y ahumada, «digna de encontrar lugar entre las fantasías báquicas y gastronómicas del cura de Meudon».

La verdad es que la «paleta holandesa» que Menéndez Pelayo atribuye al Arcipreste en esta evocación podría sin exageración pasar a su propiedad, hasta tal punto autor estudiado y crítico se funden.

Segundo ejemplo. En cuanto a caracteres y transformaciones de una forma literaria, es inevitable señalar la parte tercera, dedicada a Boscán, de esta misma Antología.

Si se pregunta a cualquier persona culta, aunque no haya leído un solo verso de Boscán, cuál es la representación de este autor en el cuadro de la literatura española, contestará sin vacilar que a Boscán se debe la introducción de las formas líricas 
de la escuela italiana en el Parnaso de Castilla, y muy especialmente la adopción del metro endecasílabo y de sus principales combinaciones. Hay en esta opinión tradicional un fondo de verdad innegable, pero requiere explicación y comento, porque nunca ha faltado quien negase a Boscán la prioridad de sus innovaciones citando varios tipos de endecasílabos conocidos en España antes del suyo (p. 141).

Menéndez Pelayo trae a colación la carta de Boscán a la Duquesa de Soma, que sirve de introducción al libro segundo de sus poesías titulado «Sonetos y Canciones a la manera de los italianos».

Las importantes declaraciones que este prefacio contiene hubieran podido evitar algunos errores a los que en diversos tiempos han tratado de esta materia, acusando a Boscán de ignorar cosas que tenía perfectamente conocidas y deslindadas: «en el primer libro habrá vuestra señoría visto esas Coplas (quiero decillo así) hechas a la Castellana. Solía holgarse con ellas un hombre muy avisado, y a quien vuestra señoría debe conocer muy bien, que es D. Diego de Mendoza. Mas paréceme que se holgaba con ellas como con niños, y así las llamaba Redondillas. Este segundo libro terná otras cosas al modo italiano, las quales serán Sonetos y Canciones que las trovas de esta arte así han sido llamadas siempre. La manera desta es más grave y demás artificio, y, si yo no me engaño, mucho mejor que la de las otras. Mas todavía, no embargante esto, quando quise probar a hacellas, no dexé de entender que temía en esto muchos reprehensores. Porque la cosa era nueva en España, y los hombres también nuevos, a lo menos muchos dellos; y en tanta novedad era imposible no temer con cautela, y aun sin ella. Quanto más, que luego, en poniendo las manos en esto, topé con hombres que me cansaron...

Los unos se quexaban que en las trovas desta arte los consonantes no andaban tan descubiertos ni sonaban tanto como en las Castellanas. Otros decían que este verso no sabían si era verso o si era prosa. Otros argüían diciendo que esto principalmente había de ser para mujeres, y que ellas no curaban de cosas de substancia, sino del son de las palabras y de la dulzura del consonante.

Estos hombres con estas sus opiniones, me movieron a que me pusiese en entender mejor la cosa, porque, entendiéndola, viese más claro sus sinrazones. Y, así, quanto más he querido llegar esto al cabo, discurriéndolo conmigo mismo y platicándolo con otros, tanto más he visto el poco fundamento que ellos tuvieron en ponerme estos miedos. Y hanme parecido tan livianos sus argumentos, que de solo haber parado en ellos poco o mucho me corro, y así me correría agora si quisiese responder a sus escrúpulos. Que ¿quién ha de responder a hombres que no se mueven sino al son de los consonantes? Y ¿quién ha de poner en pláticas con gente que no sabe qué cosa es verso, sino aquel que calzado y vestido con el consonante, os entra de un golpe por el un oído y os sale por el otro? Pues a los otros que dicen que estas cosas no siendo sino para mujeres no han de ser muy fundadas, ¿quién ha de gastar tiempo en reprendelles? Tengo yo a las mujeres por tan substanciales, las que aciertan a sello, y aciertan muchas, que en este caso quien se pusiese a defendellas las ofendería (...) (pp. 142-143).

Y de este modo, además de otros aspectos hoy significativos, pero que no son ahora del caso, muestra expedito el camino para investigar las idas y venidas de una forma literaria y reconocer sin problema que «Petrarca fue el primero que en aquella provincia le acabó de poner en su punto y en éste se ha quedado y se quedará, creo yo, para siempre» (p. 144). 
Tercer ejemplo. De cómo manejar fuentes extranjeras de una obra es modelo la investigación sobre La Celestina que forma parte de la obra Teatro anterior a Lope de Vega (Estudio y Discursos de Crítica Histórica y Literaria).

El verdadero prototipo de La Celestina debe buscarse en una comedia latina irrepresentable, frutos de los ocios de algún erudito monje del siglo XII, el cual por buenos respetos, gustó de disfrazarse con el nombre de Pánfilo Mauriliano. Esta comedia, que no ha de confundirse, como de ordinario se hace, con el poemita llamado De Vetula (aunque una vieja haga en ella muy principal papel) lleva el título de Pamphilus de Amore o de documento Amoris y está escrito en hexámetros y pentámetros, como otras obras de su género compuestas durante la Edad Media, que son en rigor composiciones retóricas y no dramáticas, aunque ésta por excepción se presenta dividida en actos y escenas. Su argumento es muy parecido al de La Celestina, y está desenvuelto con no menos libertad de expresión, aunque con dotes literarias por todo extremo inferiores. Viene a reducirse la fábula a los amores de un mancebo llamado Pánfilo y una doncella llamada Galatea, llevados a feliz acabamiento por intercesión de una vieja (que da nombre a la comedia), y coronados con la aparición de la propia diosa Venus (...).

La comedia de Pánfilo suscitó en España, a mediados del siglo XIV, una imitación libre en verso castellano, superior por todos conceptos a su modelo: nos referimos al episodio de los amores de doña Endrina de Calatayud y don Melón de la Huerta, el más extenso e importante de los muchos fragmento misceláneos agrupados en el libro singular que lleva el nombre del Arcipreste de Hita. Pero el Arcipreste no se limitó a traducir la obra árida y descarnada de Pánfilo; sino que, sacando a los personajes de la vaguedad abstracta que tenían en la comedia del monje (remedo impotente de un arte ya fenecido), les dio carta de naturaleza española, les infundió animación y vida, y fue, realmente, el primero en crear el incomparable tipo de la vieja, esbozado con mano torpísima por el supuesto Pánfilo, y plenamente desarrollado ya con el cínico nombre de Trota-conventos por el Arcipreste de Hita. Trotaconventos es la verdadera abuela de Celestina, y a ninguno de sus predecesores debió tanto Fernando de Rojas como al Arcipreste (...).

Y, por otra parte, lo menos importante en La Celestina es el asunto mismo y el plan de la fábula. Tan sencillo es, que apenas exige el trabajo de exponerle. Y sin embargo, ¿puede darse asunto más profundamente humano? Es el drama del amor juvenil, casi infantil, drama semejante al de Julieta y Romeo; y apenas puede concebirse que la crítica no haya parado mientes en esto; distraída únicamente con los primores y atrevimientos de la parte cómica. No es La Celestina obra picaresca, ni quien tal pensó, sino tragicomedia, como su título lo dice con entera verdad; poema de amor y de expiación moral, mezcla eminentemente trágica de afectos ingenuos y poco menos que instintivos y de casos fatales, que viene a torcer o interrumpir el libre curso de la pasión humana, poniendo de manifiesto una ley superior. ¿Y qué palabras serán más próximas para declararlo, que las mismas palabras del autor en el argumento de la obra? «Calixto, de noble linaje, de claro ingenio, de gentil disposición de linda crianza, dotado de muchas gracias, de estado mediano, fue preso en el amor de Melibea, mujer moza, muy generosa, de alta y serenísima sangre, sublimada en próspero estado, una sola heredera a su padre Pleberio y de su madre muy amada; vencido el casto propósito Della, interviniendo Celestina, mala y astuta mujer, con dos sirvientes del venci- 
do Calixto, engañados y por ésta tornados desleales, presa su fidelidad con anzuelo de codicia y de deleite, vinieron los amantes y los que los ministraron en amargo y desastroso fin». (pp. 246-248).

He aquí cómo en una página, que contextualiza Celestina entre el Pamphilus de Amore y Romeo Julieta, sin dejar de mencionar el poema De Vetula, deja don Marcelino centrada la cuestión esencial de la obra estudiada.

Cuarto Ejemplo. Horacio en España, integrada en la serie Bibliografía Hispano-Latino clásica de sus Obras Completas es un ejemplo contundente del rastreo de la fortuna de un autor en un país y su influencia en la literatura de ese país. Menéndez Pelayo en un Ultílogo, cuyo apasionamiento y desmesura lamentará posteriormente, se defiende retóricamente de los ataques que pueda sufrir por el carácter erudito de su investigación:

«Para qué sirve eso? ¿Cuál es la finalidad y objetivo de tanto fárrago? ¿A qué conduce esa retahíla de traductores y comentaristas, ese indigesto catálogo de odas, epístolas, sátiras y fragmentos más o menos horacianos? ¿Cómo tolerar, en los áureos tiempos de la ciencia moderna libracos de ese jaez? ¿Cuándo se acabará la raza de los eruditos incipientes y atrabiliarios, almacenistas de hechos y de nombres, cazadores de noticias raras y enemigos implacables de la civilización y de la luz? ¡Cuánto más vale un estudio sobre el concepto de poesía lírica que todas esas estériles lucubraciones! (p. 518).

Está claro el carácter del párrafo como antífrasis, pero, fuera de que el estudio de «fortuna e influencias» no tiene por qué acabar en un mero catálogo, nadie duda (ni dudaba, creo) de la necesidad de diseñar el mapa de esa fortuna como hace de modo admirable don Marcelino. Lo de si Horacio debe ser o no modelo para la lírica castellana contemporánea y otras «utilidades» que se exhiben en el ultílogo es ya otro cantar.

En fin, mediante el recorrido analítico y la pequeña selección de textos, creo haber mostrado la importante relación de Menéndez Pelayo con la disciplina que marca la renovación de los estudios literarios del siglo XX.

\section{SigLAS}

Todas las obras de Menéndez Pelayo se citan por sus Obras Completas. Edición Nacional. Santander-Madrid, C.S.I.C., 1940-1974, LXVII volúmenes. En 1999, La Fundación Hernando de Larramendi publicó en CD ROM esta edición más los XXII volúmenes de epistolario ofrecidos por la Fundación Universitaria Española (Madrid, Digibis). Actualmente se puede consultar todo en línea.

APLC. Antología de poetas líricos castellanos

BHLC. Bibliografía hispano-latina clásica

BT. Biblioteca de traductores

CE. La Ciencia española.

ECF. Ensayos de crítica filosófica

EDCL. Estudios y discursos de crítica literaria 
EM. Escritores montañeses

HE. Historia de los heterodoxos españoles

IE. Historia de las ideas estéticas

ON. Orígenes de la novela

Pro. Introducción y programa de literatura española

\section{BIBLIOGRAFÍA CITADA}

Baldensperger, Fernand (1904). Goethe en France. Essai de littérature Comparée. Paris: Hachette.

Baasner, Frank y Francisco Cero Yus (2007). Doscientos críticos literarios en la España del siglo XIX. Diccionario biobibliográfico. Madrid: CSIC.

Bataillon, Marcel (1937). Erasme et l'Espagne. Recherches sur l'histoire spirituelle du XVI siècle. Paris: Droz. Trad.: Erasmo y España. México: F.C.E., 1950.

Beyrie, Jacques (1994). Qu'est-ce q'une littérature nationale: écriture, identité, pouvoir en Espagne. Toulouse: Presses Universitaires du Mirail.

Cabo Aseguinolaza, Fernando (2012). El lugar de la literatura española. Historia de la Literatura Española 9. José-Carlos Mainer (dir.). Barcelona: Crítica.

Cabo Aseguinolaza, Fernando; Anxo Abuín González y César Domínguez (eds.). (2010). A Comparative History of Literatures in the Iberian Peninsula. I. Amsterdam: John Benjamins P. C.

Cioranescu, Alejandro (1964). Principios de literatura comparada. La Laguna: Universidad de La Laguna.

Chevalier, Maxime (1976). Lectura y lectores en la España de los siglos XVI y XVII. Madrid: Turner.

Espagne, Michel et Werner, Michael, eds. (1994). Qu'est-ce qu'une littérature nationale? «Approaches» pour une théorie interculturelle du champ littéraire. Paris: Édition de la Maison des Sciences de L'Homme.

Etiemble, René (1974). Essais de littérature (vraiment) générale. Paris: Gallimard. Trad. Ensayos de literatura (verdaderamente) general. Madrid: Taurus, 1977.

Fokkema, Douwe W. (1982). «Comparative Literature and the New Paradigm». Canadian Review of Comparative Literature/ Revue Canadienne de Littérature Comparée, 9, pp. 1-18.

Fokkema, Douwe W. (1996). «Comparative Literature and the Problem of Canon Formation», Canadian Review of Comparative Literature/ Revue Canadienne de Littérature omparée, 23/1, 51-66.

Fox, E. Inman (1997). La invención de España. Nacionalismo liberal e identidad nacional. Madrid: Cátedra.

Garrido Gallardo, Miguel Ángel (2012). «La noción de polígrafo en Menéndez Pelayo». Cálamo Faspe, 60, 2012, pp. 105-110.

González Millán, Xoán (2006). «Menéndez Pelayo y su proyecto historiográfico de una ‘nacionalidad española' plurilingüe», Boletín de la Biblioteca de Menéndez Pelayo, 82, pp. 393-426.

Guillén, Claudio (1985). Entre lo uno y lo diverso. Introducción a la literatura comparada. Barcelona: Crítica.

Morales Moya, Antonio y Esteban de Vega, Mariano, eds. (2005). ¿Alma de España. Castilla en las interpretaciones del pasado español. Madrid: Marcial Pons.

Morón Arroyo, Ciriaco (1983). Menéndez Pelayo: hacia una nueva imagen. Santander: Sociedad Menéndez Pelayo.

Pichois, Claude et André M. Rousseau (1967). La Littérature comparée, Paris, Armand Colin. (trad)., La literatura Comparada. Madrid: Gredos, 1969. 
Valdés, Mario (1990). Toward a Theory of Comparative Literature. New York-London: Peter Lang.

Rama, Carlos M. (1982). Historia de las relaciones culturales entre España y América Latina, S. XIX. México: Fondo de Cultura Económica.

Rocamora Rocamora, José Antonio (1994). El nacionalismo ibérico (1732-1936). Valladolid: Universidad de Valladolid.

Rodríguez de la Flor, Fernando (1999). La península metafísica. Arte, literatura y pensamiento en la España de la Contrarreforma. Madrid: Biblioteca Nueva.

Romero Tobar, Leonardo, ed. (2008). Literatura y nación. La emergencia de las literaturas nacionales. Zaragoza: Prensas Universitarias.

Van Thiegem, Paul (1917). Ossian en France. Paris: Rieder.

Le préromantisme. Études d'histoire littéraire européenne (1924). Paris: Félix Alcan.

La Littérature comparée (1931). Paris: Armand Colin.

Vega, María José y Neus Carbonell (1998). La Literatura comparada: Principios y Métodos (Antología). Madrid: Gredos.

Villanueva, Darío (1994). «Literatura comparada y Teoría de la literatura», en Curso de teoría de la literatura. Darío Villanueva (ed.). Madrid: Taurus, pp. 93-128.

Vernet, Juan (1999). Lo que Europa debe al Islam de España. Barcelona: El Acantilado.

Weisstein, Ulrich (1968). Einführung in die vergleichende Literaturwissenschaft. Stuttgart: Kohlhammer. Trad.: Introducción a la literature comparada. Barcelona: Planeta, 1975.

Wellek, René (1963). Concepts of Criticism. New Haven and London: Yale University Press. Trad. Conceptos de Crítica Literaria, Caracas. Universidad Central de Venezuela, 1968.

Wellek, René (1968). «The Name and Nature of Comparative Literature», en Discriminations. Further Concepts of Literary Criticism. New Haven and London:Yale University Press, 1970, pp. 1-36.

Zima, Peter (1992). Komparatistik. Tübingen: Francke.

Fecha de recepción: 4 de julio de 2011

Fecha de aceptación: 12 de diciembre de 2011 